\title{
RADIASI PLASMA PIJAR KORONA TERHADAP PERTUMBUHAN DAN KANDUNGAN NITROGEN TOTAL BAWANG MERAH DAN BAWANG BOMBAY
}

\section{CORONA GLOW DISCHARGE PLASMA RADIATION TO GROWTH AND TOTAL NITROGEN OF SHALLOTS AND ONIONS}

\author{
Ariyanti ${ }^{1}$, Erma Prihastanti ${ }^{*}$, dan Much. Azam² \\ 1 Departemen Biologi, Fakultas Sains dan Matematika, Universitas Diponegoro, Indonesia \\ 2 Departemen Fisika, Fakultas Sains dan Matematika, Universitas Diponegoro, Indonesia
}

Diterima : 01-07-2019; Disetujui : 10-12-19: Diterbitkan : 10-02-2020

*Corresponding author: E-mail: eprihast@yahoo.co.id

\begin{abstract}
Abstrak
Bawang merah dan bawang bombay merupakan komoditi sayur yang banyak dikonsumsi oleh masyarakat. Pasokan kedua varietas bawang ini di Indonesia tidak tersedia sepanjang waktu karena budidaya bawang merah dilakukan secara musiman. Oleh karena itu perlu adanya peningkatan budidaya bawang salah satunya melalui penambahan nitrogen melalui teknologi plasma. Penelitian ini bertujuan untuk mengetahui adanya pengaruh pemberian nitrogen melalui plasma teknologi plasma terhadap pertumbuhan bawang merah bima brebes dan bawang bombay grano. Penelitian menggunakan metode Rancangan Acak Lengkap (RAL) yang terdiri dari 6 perlakuan dengan 5 kali ulangan. Radiasi plasma dilakukan pada bibit bawang merah dan bawang bombay dengan jarak waktu penyinaran 0, 15, dan 30 menit. Parameter pertumbuhan yang diamati yaitu waktu tumbuh tunas, persentase pertunasan, panjang akar, jumlah akar, tinggi tanaman, jumlah tunas, dan kandungan nitrogen. Data dianalisis menggunakan ANOVA yang dilanjutkan dengan Uji DMRT pada taraf kepercayaan 95\%. Hasil penelitian menunjukkan bahwa pada bawang merah yang diradiasi plasma selama 15 menit dapat meningkatkan pertumbuhan dan kandungan nitrogen total, sedangkan pada bawang bombay, hasil tertinggi terdapat pada perlakuan kontrol (radiasi 0 menit). Pada bawang bombay, pemberian plasma dapat menghambat pertumbuhan dan kandungan nitrogen total sebesar $0,31 \%$, akan tetapi dapat meningkatkan jumlah akar.
\end{abstract}

Kata Kunci: bawang merah, bawang bombay, radiasi plasma, nitrogen, pertumbuhan

\begin{abstract}
Shallots and onions are one of the leading vegetable commodities consumed by the public. The supply of these two onion varieties in Indonesia is not available at all times because it is done seasonally. Therefore it is necessary to increase the cultivation, one of which is through the addition of nitrogen through plasma technology. This study to determine the effect of giving plasma nitrogen through plasma technology to the growth of bima onion Brebes and grano onions. The study used a Completely Randomized Design (CRD) consisting of 6 treatments with five replications. Plasma radiation is carried out on onion seeds and onions with a radiation interval of 15 and 30 minutes. The growth parameters observed were shoot growth time, growth percentage, root length, number of roots, plant height, number of shoots, and nitrogen content. Data were analyzed using ANOVA followed by DMRT Test at 95\% confidence level. The results showed that the onion irradiated by plasma for 15 minutes could increase growth and total nitrogen content, while in onions, the highest yield was precisely in the control treatment (0-minute radiation). In onions, plasma administration can inhibit growth and total nitrogen content 0,31\% but can increase the number of roots.
\end{abstract}

Key Words: local shallot, corona incandescent plasma discharge, goat fertilizer, plant growth

How to Cite: Ariyanti, Prihastanti, E., dan Azam, Much. (2020). Radiasi Plasma Pijar Korona Terhadap Pertumbuhan dan Kandungan Nitrogen Total Bawang Merah dan Bawang Bombay, BioLink: Jurnal Biologi Lingkungan, Industri dan Kesehatan, Vol.6 (2): Hal. 126-137 
Ariyanti, Prihastanti, E., dan Azam, Much. Radiasi Plasma Pijar korona Terhadap Pertumbuhan dan Kandungan Nitrogen Total Bawang Merah dan Bawang Bombay

PENDAHULUAN

Bawang merupakan komoditas hortikultura berjenis umbi lapis yang memiliki banyak manfaat dan nilai ekonomis tinggi (Medina dan Hariyono, 2019). Bawang merah dan bawang bombay merupakan satu jenis dan berasal dari Genus yang sama (Pramukyana dkk, 2018). Produktivitas bawang merah nasional pada tahun 2011-2014 rata-rata 9,85 ton/ha, namun belum mampu memenuhi kebutuhan nasional dikarenakan bertambahnya jumlah penduduk dan berkembangnya industri olahan makanan semakin meningkat (Nugroho dkk, 2017). Hal tersebut berpengaruh terhadap harga bawang dalam skala nasional, sehingga harga bawang mengalami fluktuasi yang tinggi dan tidak dapat dieksport ke Luar negeri, padahal tidak semua Negara memiliki musim yang cocok untuk menanam bawang (Kusuma, 2013).

Rendahnya produksi benih bawang nasional disebabkan belum banyaknya produsen yang mau bergerak dibidang perbenihan bawang. Kendala tersebut disebabkan antara lain karena usaha perbenihan bawang membutuhkan modal yang cukup tinggi dan areal serta gudang yang luas, pengetahuan dan ketrampilan Sumber Daya Manusia terutama dalam produksi benih masih rendah, daya simpan benih bawang rendah (2-5 bulan) dengan susut bobot yang tinggi, permasalahan penyimpanan benih dapat diatasi dengan pembentukan benih berupa biji, namun sayangnya keterampilan ini cukup sulit diaplikasikan pada petani. Adanya keterbatasan produksi benih bawang nasional menyebabkan Indonesia belum mampu memenuhi kebutuhan benih nasional, oleh karena itu Indonesia mengimpor benih bawang dari beberapa negara seperti Philipina, Vietnam, dan Thailand (Elisabeth, 2013).

Salah satu unsur hara penting untuk pertumbuhan bawang merah dan bawang bombay yaitu nitrogen. Nitrogen adalah unsur hara yang cepat mengalami perpindahan, mudah sekali terurai atau larut dalam tanah oleh dan mudah menguap, sehingga tanaman seringkali mengalami defisiensi (Fahmi $d k k, 2010)$. Nitrogen mudah terkuras dikarenakan sifatnya yang mudah larut, terbawa saat panen dan erosi (Jemrifs dan Sonbai, 2013).

Sumber nitrogen yang melimpah berasal dari udara bebas dengan komposisi nitrogen mencapai $80 \%$. Melalui teknologi peradiasian plasma pada udara bebas berpotensi besar menghasilkan ion $\mathrm{N}^{+}$. Upaya peningkatan kualitas dan produktivitas tanaman sayur dapat dilakukan dengan pengkayaan unsur nitrogen yang disisipkan dalam benih. Dalam hal ini, teknologi plasma 
mensuplai kebutuhan nitrogen tanaman secara langsung dari udara lewat penyusupan ion $\mathrm{N}+$ (Nadzifah dan Prihastanti, 2019). Teknologi plasma dapat digunakan sebagai upaya untuk menekan penggunaan pupuk anorganik serta meningkatkan kualitas produksi bawang merah lokal.

Keunggulan dari teknologi plasma yaitu nitrogen yang disusupkan dalam biji dapat langsung terikat karena awalnya berbentuk ion $\mathrm{N}_{2}{ }^{+}$atau $\mathrm{N}^{+}$dari proses disosiasi diikuti dengan ionisasi atau proses ionisasi molekul (Nur $d k k, 2011$ ). Dengan adanya ion nitrogen yang terdifusi kedalam biji mampu meningkatkan kadar nitrogen dalam biji, sehingga dapat mendukung pertumbuhan. Tujuan dari penelitian ini adalah mengetahui pengaruh radiasi plasma terhadap pertumbuhan dan kandungan nitrogen total pada bawang merah varietas bima brebes dan bawang Bombay varietas grano.

\section{METODE PENELITIAN}

Penelitian ini dilakukan pada bulan September 2018 sampai November 2018. Tempat penelitian dilakukan di Laboratorium BSF Tumbuhan Departemen Biologi dan Laboratorium CPR (Center Plasma Research) Departemen Fisika, Fakultas Sains dan Matematika, Universitas Diponegoro, Semarang.
Alat yang digunakan adalah cawan petri, seperangkat system reactor plasma lucutan pijar korona yang terdiri dari, sumber tegangan DC, voltmeter, amperemeter, sterofoam, elektroda bidang dan elektroda titik, cutter, sprayer, penggaris, alat tulis, kamera, timbangan digital, dan mortar pestle.

Bahan yang digunakan adalah bibit bawang merah varietas bima brebes dan bawang bombay varietas, kertas label, air, gelas pop ice, kapas, dan milimeter blok.

Cara kerja yang dilakukan yaitu pertama seleksi bibit. Bibit bawang merah var. bima brebes dan bawang bombay ditimbang berat awalnya dengan menggunakan timbangan digital. Bibit bawang merah dan bawang bombay yang telah ditimbang untuk mendapatkan ukuran dan bentuk yang seragam. Kedua yaitu proses radiasi plasma. Alat yang digunakan yaitu plasma lucutan pijar korona. Bibit bawang merah dan bawang bombay yang telah diseleksi kemudian akan diberi perlakuan radiasi selama 0 menit, 15 menit, dan 30 menit. Penyinaran dilakukan dengan cara bibit bawang merah var. bima brebes dan bawang bombay grano diletakkan pada elektroda bidang dengan posisi bagian akar berada di bagian atas. Besarnya arus pada pembangkit sebesar 2,5 mA dan tegangan $14 \mathrm{kV}$. Jarak antara elektroda titik dengan elektroda bidang yaitu $3 \mathrm{~cm}$. Ketiga, yaitu 
Ariyanti, Prihastanti, E., dan Azam, Much. Radiasi Plasma Pijar korona Terhadap Pertumbuhan dan Kandungan Nitrogen Total Bawang Merah dan Bawang Bombay

proses budidaya yang meliputi persiapan kedua yaitu waktu radiasi plasma : tidak media tanam. Media tanam yang diradiasi $\left(\mathrm{R}_{0}\right)$, diradiasi selama 15 menit digunakan yaitu botol air minum bekas. ( $\left.\mathrm{R}_{15}\right)$, dan diradiasi selama 30 menit $\left(\mathrm{R}_{30}\right)$. Botol air minum bekas diisi dengan kapas kemudian diberi air secukupnya. Keempat, proses penanaman. Bibit dipotong 1/3 bagian dari akar. Bibit dimasukkan ke dalam botol air minum bekas yang sebelumnya telah diisi air dan kapas. Bagian akar bibit tersebut harus tergenang air agar mempercepat proses pertumbuhan.

Proses terakhir adalah pemeliharaan. Proses pemeliharaan bibit bawang dilakukan dengan penyiraman setiap 2 hari sekali dan konrol untuk menghindari adanya hama yang dapat mengganggu pertumbuhan bawang.

Penelitian ini dilakukan dengan menggunakan Rancangan Acak Lengkap (RAL) dengan 6 perlakuan dan 5 kali pengulangan. Faktor pertama yaitu variasi bawang : bawang merah bima brebes (BM) Tabel 1. Rancangan Perlakuan Penelitian

\begin{tabular}{cccc}
\hline $\mathbf{B} / \mathbf{R}$ & $\mathbf{R}_{\mathbf{0}}$ & $\mathbf{R}_{15}$ & $\mathbf{R}_{\mathbf{3 0}}$ \\
\hline $\mathbf{B}_{\mathbf{M}}$ & $\mathrm{B}_{\mathrm{M}} \mathrm{R}_{0}$ & $\mathrm{~B}_{\mathrm{M}} \mathrm{R}_{15}$ & $\mathrm{~B}_{\mathrm{M}} \mathrm{R}_{30}$ \\
$\mathbf{B}_{\mathbf{B}}$ & $\mathrm{B}_{\mathrm{B}} \mathrm{R}_{0}$ & $\mathrm{~B}_{\mathrm{B}} \mathrm{R}_{15}$ & $\mathrm{~B}_{\mathrm{B}} \mathrm{R}_{30}$ \\
\hline
\end{tabular}

Keterangan :

a. $\mathrm{BM}_{\mathrm{M}}=$ Bawang Merah Varietas Bima Brebes

b. $\mathrm{B}_{\mathrm{B}}=$ Bawang Bombay

c. $\mathrm{R}_{0}=$ Radiasi 0 menit

d. $\mathrm{R}_{15}=$ Radiasi selama 15 menit $\mathrm{R}_{30}=$ Radiasi selama 30 menit

HASIL DAN PEMBAHASAN

Pengaruh Radiasi Plasma terhadap Kandungan Nitrogen Total Tanaman Bawang Merah var. Bima Brebes dan Bawang Bombay var. Grano

Hasil uji ANOVA (Analysis of Variance) pada taraf signifikasi 95\%, menunjukkan adanya pengaruh interaksi yang tidak berbeda nyata faktor perlakuan radiasi plasma dan variasi jenis bawang terhadap parameter kandungan nitrogen total (Tabel 2.).

dan bawang bombay grano($\left(\mathrm{B}_{\mathrm{B}}\right)$. Faktor

Tabel 2. Hasil analisis parameter kandungan nitrogen total tanaman bawang merah varietas bima brebes dan bawang bombay varietas grano dengan perlakuan penyinaran plasma pijar korona

\begin{tabular}{cc}
\hline \multirow{2}{*}{ Perlakuan } & Parameter \\
\cline { 2 - 2 } & Kandungan Nitrogen Total (\%) \\
\hline $\mathrm{B}_{\mathrm{M}} \mathrm{R}_{0}$ & 2,1 \\
$\mathrm{~B}_{\mathrm{M}} \mathrm{R}_{15}$ & 2,1 \\
$\mathrm{~B}_{\mathrm{M}} \mathrm{R}_{30}$ & 2,09 \\
$\mathrm{~B}_{\mathrm{B}} \mathrm{R}_{0}$ & 2,6 \\
$\mathrm{~B}_{\mathrm{B}} \mathrm{R}_{15}$ & 2,38 \\
$\mathrm{~B}_{\mathrm{B}} \mathrm{R}_{30}$ & 2,29 \\
\hline
\end{tabular}


Hasil rata-rata kandungan nitrogen total tanaman bawang merah dan bawang bombay yang diberi perlakuan radiasi dapat dilihat pada Gambar 1.

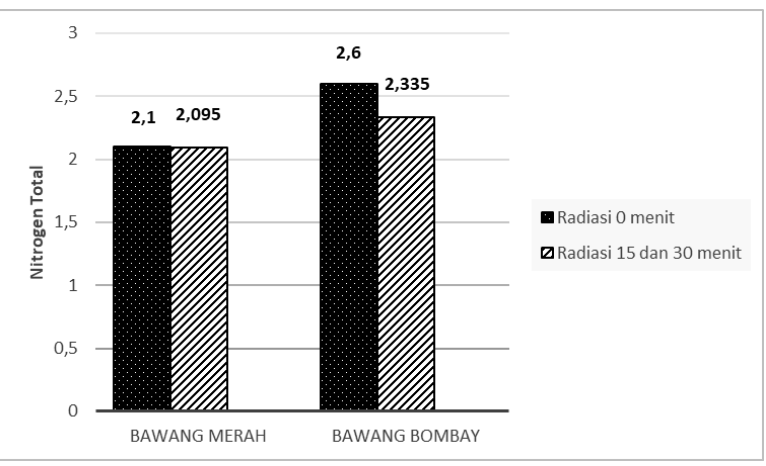

Gambar 1. Histogram rata-rata kandungan nitrogen total bawang merah dan bawang bombay kontrol (radiasi 0 menit) dengan rata-rata radiasi 15 menit dan 30 menit

Gambar 1. menunjukkan bahwa perlakuan radiasi plasma pijar korona menurunkan kandungan nitrogren total pada tanaman bawang merah dan tanaman bawang bombay. Penurunan yang paling signifikan yaitu pada bawang bombay, yang awalnya 2,6\% kemudian setelah diradiasi selama 15 menit menjadi $2,3 \%$, sementara pada bawang bombay penurunannya tidak begitu banyak, hanya selisih 0,005 dari kandungan nitrogen total sebelum diradiasi. Kandungan nitrogen total sebelum diradiasi pada merah jumlahnya lebih kecil dibandingkan dengan kandungan nitrogen total pada bawang bombay sebelum diradiasi. Bawang merah hanya 2,1\%, sedangkan bawang bombay $2,6 \%$.

Pengaruh Radiasi Plasma terhadap Pertumbuhan Tanaman Bawang Merah
Varietas Bima Brebes dan Bawang Bombay Grano

Hasil ANOVA (Analysis of Variance) pada taraf signifikasi 95\%, menunjukkan adanya pengaruh interaksi yang berbeda nyata faktor perlakuan radiasi plasma dan variasi jenis bawang terhadap parameter pertumbuhan panjang akar dan tinggi tanaman, namun tidak terdapat interaksi kedua faktor perlakuan terhadap parameter pertumbuhan jumlah tunas dan jumlah akar.

\section{a. Persentase Pertunasan}

Hasil uji ANOVA menunjukkan bahwa masing - masing perlakuan radiasi plasma dan variasi jenis bawang tidak memberikan pengaruh yang berbeda nyata terhadap persentase tumbuh tunas kedua jenis tanaman, begitupun dengan interaksi kedua faktor perlakuan. Hasil rata-rata persentase tumbuh tunas yang diberi perlakuan radiasi dapat dilihat pada Gambar 2.

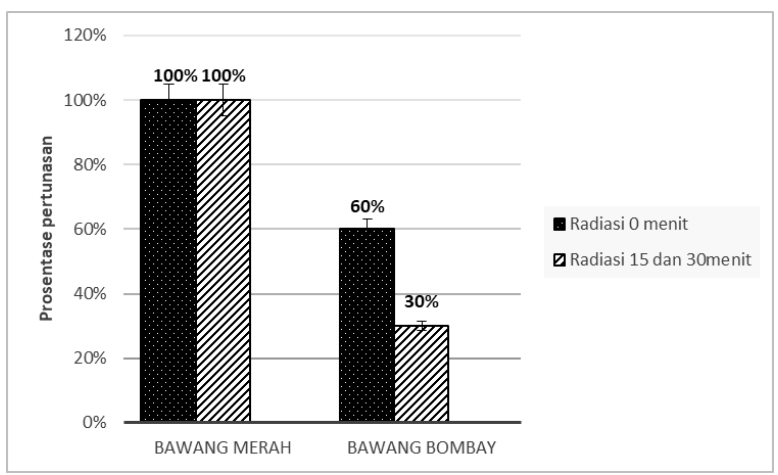

Gambar 2. Histogram rata-rata prosentase pertunasan pada hari ke-14 bawang merah dan bawang bombay kontrol (radiasi 0 menit) dengan rata-rata radiasi 15 menit dan 30 menit 
Ariyanti, Prihastanti, E., dan Azam, Much. Radiasi Plasma Pijar korona Terhadap Pertumbuhan dan Kandungan Nitrogen Total Bawang Merah dan Bawang Bombay

Gambar 2. menunjukkan bahwa (radiasi 0 menit) dengan rata-rata radiasi 15 menit perlakuan radiasi plasma pijar korona Gambar 3. menunjukkan bahwa tidak berpengaruh terhadap persentase pada bawang merah, baik radiasi 0 menit (kontrol), 15 menit dan 30 menit menghasilkan jumlah pertunasan 100\%, akan tetapi pada bawang bombay terjadi penurunan persentase pertunasan antara perlakuan kontrol dan radiasi selama 15 menit maupun 30 menit, yaitu pada perlakuan kontrol persentase pertunasan sebanyak $60 \%$, sedangkan pada perlakuan yang diradiasi sebanyak 30\%. Hal ini menujukkan bahwa bawang bombay yang diradiasi mengalami penurunan pertumbuhan sebesar 50\% dari kontrol. Perbandingan antara persentase pertunasan.

\section{b. Waktu Tumbuh Tunas}

$$
\text { Hasil analisis }
$$

menunjukkan tidak adanya interaksi faktor perlakuan radiasi plasma dan variasi jenis bawang terhadap parameter waktu tumbuh tunas. Hasil rata-rata jumlah tunas yang diberi perlakuan radiasi dapat dilihat pada Gambar 3.

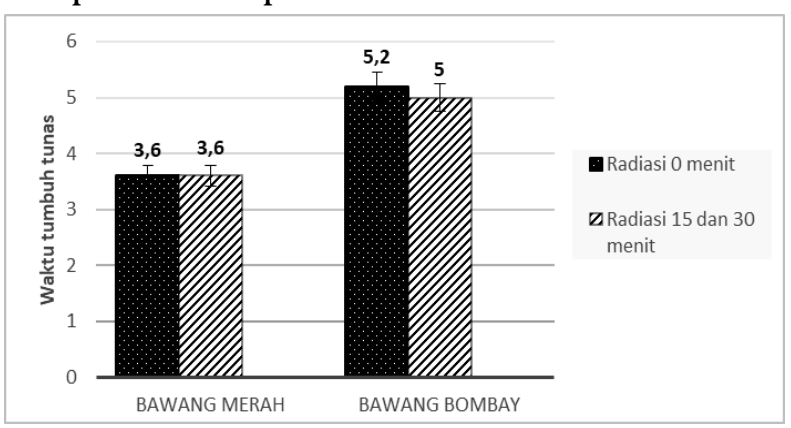

Gambar 3. Histogram rata-rata waktu tumbuh tunas bawang merah dan bawang bombay kontrol

perlakuan radiasi plasma pijar korona tidak berpengaruh terhadap waktu tumbuh tunas pada bawang merah, baik radiasi 0 menit (kontrol), radiasi 15 menit dan 30 menit memiliki waktu tumbuh tunas pada hari ke 3,6, sementara pada bawang bombay radiasi plasma mempercepat waktu tumbuh tunas namun tidak begitu signifikan. Perlakuan kontrol pada bawang merah dan bawang bombay dapat dilihat bahwa waktu tumbuh lebih cepat yaitu pada hari ke 3 dan hari ke 5 .

\section{c. Jumlah Tunas}

Hasil analisis (ANOVA) menunjukkan tidak adanya interaksi faktor perlakuan radiasi plasma dan variasi jenis bawang terhadap parameter jumlah tunas. Hasil rata-rata jumlah tunas yang diberi perlakuan radiasi dapat dilihat pada Gambar 4.

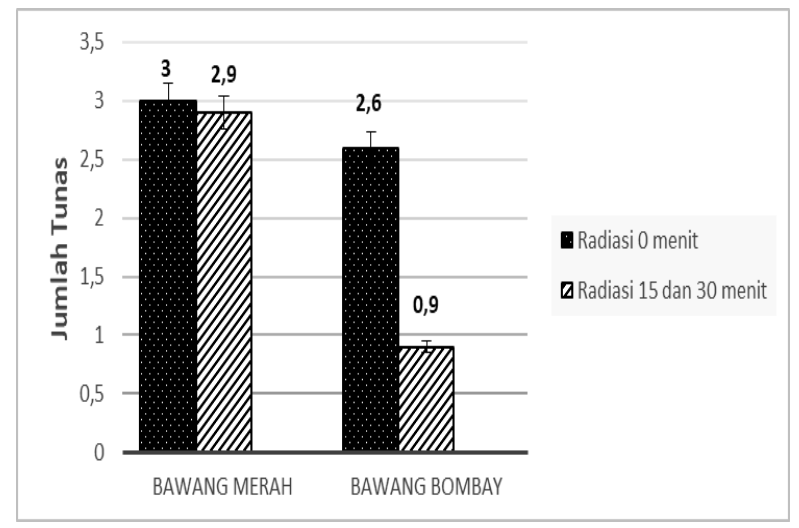

Gambar 4. Histogram rata-rata jumlah tunas bawang merah dan bawang bombay kontrol (radiasi 0 menit) dengan rata-rata radiasi 15 menit dan 30 menit 
Gambar 4. menunjukkan bahwa perlakuan radiasi plasma pijar korona menyebabkan penurunan yang tidak begitu signifikan terhadap parameter jumlah tunas pada bawang merah. Radiasi 0 menit jumlah tunasnya sebanyak 3 tunas, sedangkan radiasi 15 menit dan 30 menit rata-rata jumlah tunas 2,9, sementara pada bawang bombay terjadi penurunan yang sangat signifikan pada perlakuan radiasi plasma. Radiasi 0 menit rata-rata 2,6 tunas, sedangkan pada radiasi 15 menit dan 30 menit rata-rata 0,6 tunas. Perbandingan antara jumlah tunas bawang merah dan bawang bombay kontrol yaitu sebanyak 3 tunas dan 2,6 tunas.

\section{d. Panjang Akar}

Hasil uji DMRT (Duncan Multiple Range Test) menunjukkan bahwa masingmasing perlakuan radiasi plasma dan variasi jenis bawang memberikan pengaruh yang berbeda nyata terhadap panjang akar kedua jenis tanaman, begitupun dengan interaksi kedua faktor perlakuan. Hasil rata-rata panjang akar yang diberi perlakuan radiasi dapat dilihat pada Gambar 5.

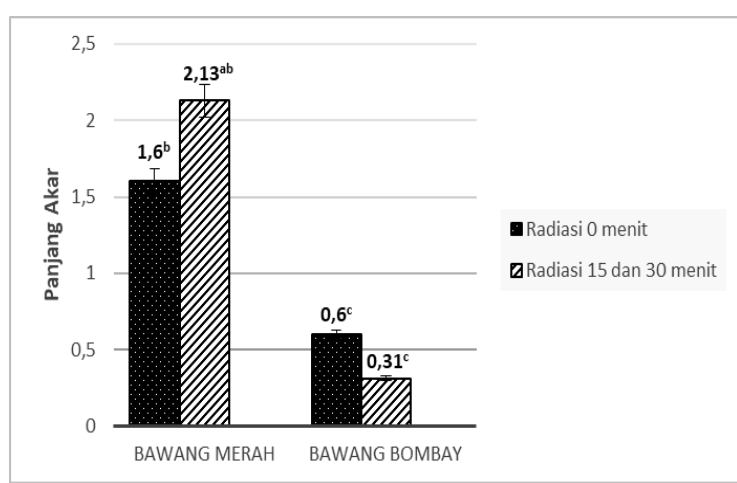

Gambar 5. Histogram rata-rata panjang akar bawang merah dan bawang Bombay kontrol (radiasi 0 menit) dengan rata-rata radiasi 15 menit dan 30 menit

Gambar 5. menunjukkan bahwa perlakuan radiasi plasma pijar korona menyebabkan peningkatan pertumbuhan parameter panjang akar pada bawang merah. Radiasi 0 menit rata-rata panjang akar 1,6 cm, sedangkan, radiasi 15 menit dan 30 menit rata-rata panjang akar 2,13 cm. Panjang akar bawang bombay terjadi penurunan pada perlakuan radiasi plasma. Radiasi 0 menit rata-rata panjang akar 0,6 cm, sedangkan pada radiasi 15 menit dan 30 menit rata-rata panjang akar 0,31 cm. Perbandingan antara rata-rata panjang akar bawang merah dan bawang bombay kontrol yaitu $1,6 \mathrm{~cm}$ dan $0,6 \mathrm{~cm}$.

\section{e. Jumlah Akar}

$$
\text { Hasil analisis }
$$

(ANOVA)

menunjukkan tidak adanya interaksi faktor perlakuan radiasi plasma dan variasi jenis bawang terhadap parameter jumlah akar. Hasil rata-rata jumlah tunas yang diberi perlakuan radiasi dapat dilihat pada Gambar 6. 


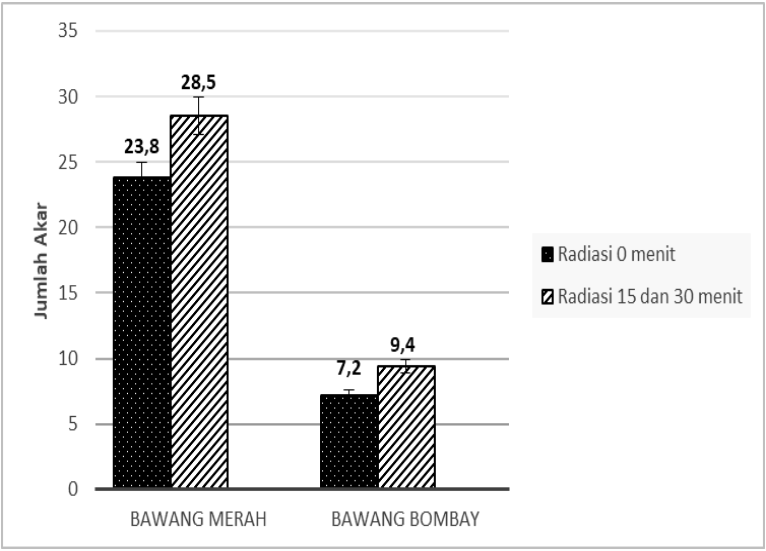

Gambar 6. Histogram rata-rata jumlah akar bawang merah dan bawang bombay kontrol (radiasi 0 menit) dengan rata-rata radiasi 15 menit dan 30 menit

Gambar 6. menunjukkan bahwa perlakuan radiasi plasma pijar korona menyebabkan peningkatan pertumbuhan parameter jumlah akar pada bawang merah dan bombay. Rata-rata jumlah akar pada bawang merah radiasi 0 menit yaitu sebanyak 23,8, sedangkan, radiasi 15 menit dan 30 menit rata-rata jumlah akar 28,5, sementara pada bawang bombay rata-rata jumlah akar yang diradiasi 0 menit yaitu 7,2, sedangkan radiasi 15 menit dan 30 menit rata-rata jumlah akar 9,4. Hal ini menunjukkan bahwa plasma berpengaruh terhadap parameter jumlah akar bawang merah dan bombay. Perbandingan antara rata-rata jumlah akar bawang merah dan bawang bombay kontrol yaitu sebanyak 23,8 dan 7,2.

\section{f. Tinggi Tanaman}

Hasil uji DMRT (Duncan Multiple Range Test) menunjukkan bahwa masing masing perlakuan radiasi plasma dan variasi jenis bawang memberikan pengaruh yang berbeda nyata terhadap tinggi tanaman kedua jenis tanaman, begitupun dengan interaksi kedua faktor perlakuan. Hasil rata-rata panjang akar yang diberi perlakuan radiasi dapat dilihat pada Gambar 7.

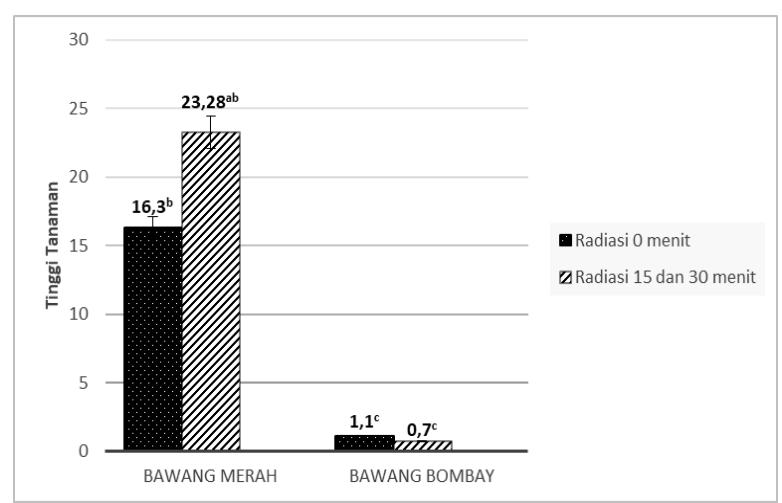

Gambar 7 Histogram rata-rata tinggi tanaman bawang merah dan bawang bombay kontrol (radiasi 0 menit) dengan rata-rata radiasi 15 menit dan 30 menit

Gambar 7. menunjukkan bahwa perlakuan radiasi plasma pijar korona menyebabkan peningkatan pertumbuhan parameter tinggi tanaman pada bawang merah. Radiasi 0 menit rata-rata tinggi tanaman $16,3 \mathrm{~cm}$, sedangkan radiasi 15 menit dan 30 menit rata-rata tinggi tanaman yaitu 23,28 cm. Tinggi tanaman bawang bombay terjadi penurunan pada perlakuan radiasi plasma. Radiasi 0 menit rata-rata tinggi tanaman yaitu $1,1 \mathrm{~cm}$, sedangkan pada radiasi 15 menit dan 30 menit rata-rata panjang akar yaitu 0,7 cm. Perbandingan antara rata-rata tinggi tanaman bawang merah dan bawang bombay kontrol yaitu sepanjang 16,3 cm dan $1,1 \mathrm{~cm}$. 
Berdasarkan pendapat Nur dkk., pertumbuhan. Radiasi plasma pada (2011), Plasma merupakan daerah reaksi bawang merah yang optimal yaitu pada tumbukan elektron yang sangat signifikan untuk terjadi. Plasma dapat terjadi ketika temperatur atau energi suatu gas dinaikkan sehingga memungkinkan atomatom gas terionisasi akan membuat gas tersebut melepaskan elektronelektronnya yang pada keadaan normal mengelilingi inti.

Menurut Shobarudin dan Nur (2013), ion nitrogen yang bermuatan positif akan tertarik oleh medan negatif/elektroda negatif (elektroda bidang) sehingga ion nitrogen akan terdeposisi ke sampel yang diletakkan di elektroda negatif dan akan meningkatkan kadar nitrogen sampel.

Berdasarkan penelitian yang telah dilakukan, didapatkan hasil bahwa pemberian radiasi plasma berpengaruh terhadap parameter presentase tumbuh tunas, panjang akar, tinggi tanaman, serta jumlah nitrogen total pada kedua jenis tanaman, sedangkan parameter jumlah tunas dan jumlah akar tidak berpengaruh. Hasil penelitian menunjukkan bahwa perlakuan radiasi plasma pijar korona dapat meningkatkan pertumbuhan vegetatif pada tanaman bawang merah seiring dengan semakin lama radiasi yang dilakukan, namun pada tanaman bawang bombay, durasi radiasi plasma yang semakin lama mengakibatkan penurunan perlakuan $\mathrm{R}_{15}$ (radiasi 15 menit), sedangkan pada tanaman bawang bombay, durasi radiasi plasma yang semakin lama mengakibatkan penurunan pertumbuhan.

Penelitian Puspitasari

(2018), menunjukkan bahwa radiasi plasma mampu meningktakan pertumbuhan dan produksi bawang merah. Radiasi selama 15 mampu meningkatkan pertumbuhan sebesar 9,53\% sedangkan produksinya mampu meningkatkan berat basah sebesar $17,44 \%$.

Berdasarkan data yang didapat, dapat diketahui bahwa plasma berperan dalam mempercepat tumbuhnya tunas tanaman, pada penelitian ini waktu penyinaran yang paling optimal yaitu pada waktu penyinaran 15 menit. Menurut Nur dkk (2013) plasma lucutan pijar korona mampu mempercepat proses pertumbuhan pada persemaian biji mangrove. Waktu penyinaran yang optimal untuk pertumbuhan tanaman bawang merah menurut Puspitasari dkk (2018) yaitu 15 menit dimana pada penelitian tersebut pada perlakuan bibit yang disinari selama 15 menit menunjukkan data pertumbuhan yang lebih baik dibandingkan dengan waktu penyinaran 0 menit dan 30 menit. 
Hasil uji kandungan nitrogen total didapatkan hasil bahwa kandungan nitrogen total paling tinggi pada bawang merah yaitu pada perlakuan $\mathrm{R}_{0}$ (kontrol) dan $\mathrm{R}_{15}$ (radiasi 15 menit), sedangkan kandungan nitrogen total paling tinggi pada bawang jombay justru pada perlakuan $\mathrm{R}_{0} \quad$ (kontrol). Kandungan nitrogen total pada tanaman berhubungan dengan kandungan klorofil pada suatu tanaman tersebut. Salah satu unsur hara yang paling dibutuhkan oleh tanaman yaitu nitrogen. Peran nitrogen pada daun yaitu merangsang pembentukan daun dan memberikan efek warna hijau tua pada tanaman. Filho (2011) menyebutkan bahwa penambahan $\mathrm{N}$ mendorong pembentukan pigmen fotosintesis aktif dengan meningkatkan jumlah protein stroma dan tilakoid serta meningkatkan pembentukan kloroplas selama pertumbuhan daun. Hasil penelitian menunjukkan bahwa perlakuan radiasi plasma pijar korona dapat meningkatkan pertumbuhan vegetatif pada tanaman bawang merah seiring dengan semakin lama radiasi yang dilakukan, namun pada tanaman bawang bombay, durasi radiasi plasma yang semakin lama mengakibatkan penurunan pertumbuhan. Hal ini bisa terjadi karena perbedaan morfologi dan fisiologi dari masingmasing tanaman tersebut berakibat pada penyerapan ion nitrogen ke dalam sel umbi bawang, sehingga pada bawang merah pemberian plasma yang optimal dapat meningkatkan pertumbuhan dan perkembangan tanaman, sedangkan pada bawang bombay, pemberian plasma pijar korona justru menurunkan pertumbuhan dan perkembangan dari tanaman tersebut. Pemberian ion nitrogen menggunakan teknologi plasma pijar korona memberikan hasil yang berbedabeda pada setiap jenis tanaman. Setiap tanaman juga mempunya waktu optimal yang berbeda ketika diradiasi menggunakan plasma. Menurut penelitian yang dilakukan oleh Nucifera et.al (2016) menyebutkan bahwa adanya pengaruh pemberian plasma selama 30 menit terhadap jumlah daun kedelai hitam dimana pada perlakuan ini jumlah daunnya lebih banyak.

Hal lain yang menyebabkan penurunan pertumbuhan pada bawang bombay yaitu akibat suhu plasma yang semakin tinggi seiring dengan lama waktu radiasi yang dilakukan, dan hal ini berhubungan erat dengan enzim. karena enzim tersusun dari protein, enzim sangat peka terhadap temperatur. Pada suhu yang terlalu tinggi menyebabkan denaturasi pada protein. Suhu yang terlalu tinggi menyebabkan enzim tidak bekerja karena struktur enzim mengalami 
denaturasi protein. Enzim yang mengalami denaturasi tidak dapat digunakan kembali.

Jika enzim rusak maka aktivitas enzim terganggu maka reaksi metabolisme sel akan terhambat hingga pertumbuhan sel juga terganggu.

\section{SIMPULAN}

Berdasarkan penelitian yang telah dilakukan dapat disimpulkan bahwa lama waktu penyinaran radiasi plasma berpengaruh terhadap pertumbuhan dan kandungan nitrogen total bawang merah var. bima brebes, yaitu optimal pada waktu penyinaran 15 menit, akan tetapi pada bawang bombay var. grano (Allium cepa var. grano) semakin lama waktu penyinaran dapat menurunkan partumbuhannya. Faktor jenis bawang berpengaruh terhadap pertumbuhan dan kandungan nitrogen total bawang merah var. bima brebes (Allium cepa var. bima brebes) dan bawang bombay var. grano (Allium cepa var. grano). Pertumbuhan bawang merah lebih baik dibandingkan dengan bawang Bombay kerena adanya kenaikan temperatur suhu saat proses penyinaran radiasi. Kombinasi perlakuan yang paling optimal yaitu pada $\mathrm{B}_{\mathrm{M}} \mathrm{R}_{15}$ dan $\mathrm{B}_{\mathrm{B}} \mathrm{R}_{0}$.

\section{UCAPAN TERIMA KASIH}

Terima kasih kepada Badan Penelitian Lingkungan Pertanian Pati (balingtan) yang telah menguji kandungan nitrogen total pada bawang merah dan bombay. Terim kasih saya ucapkan juga kepada Laboratorium BSF Tumbuhan Departemen Biologi dan Laboratorium CPR (Center Plasma Research) Departemen Fisika, Fakultas Sains dan Matematika, Universitas Diponegoro, Semarang.

\section{DAFTAR PUSTAKA}

Filho MCMT, Buzetti S, Andeotti M, Arf O, de Sa'ME. (2011). Application Times, Sources and Doses of Nitrogen on Wheat Cultivars Under No Till in The Cerrado Region. Ciência Rural. 2011; 41(8):1375-1382.

Hayati, E., Mahmud, T., dan Fazil, R. (2012). Pengaruh Jenis Pupuk Organik dan Varietas Terhadap Pertumbuhan dan Hasil Tanaman Cabai (Capsicum annum L.). J. Floratek 7: $173-181$.

Indah, I. M., dan Maharijaya, A. (2016). Keragaan Bawang Merah (Allium ascalonicum L.) IPB di Tiga Lokasi. IPB : Bogor.

Jemrifs, H dan H. Sonbai. (2013). Pertumbuhan dan Hasil pada Berbagai Pemberian Puouk Nitrogen di Lahan Kering Regosol. Partner. 20(2): 154-164.

Medina. S dan D. Hariyono. (2019). Pengaruh Berbagai Jenis Mulsa Terhadap Pertumbuhan dan Hasil Tiga Varietas BAwang Merah (Allum ascalonicum L.). Jurnal Produksi Tanaman. 7 (3): 531-537.

Nadzifah. U dan E. Pihastanti. (2019). Pengaruh Radiasi Plasma PijarKorona Terhadap Viabilitas, Laju perkecambahan dan Morfologi Kecambah Biji Bayam Cabut (Amaranthus tricolor L.). Jurnal Biologi Tropika. 2(1): 28-33.

Nucifera, N., Kanie, M. A., Pratiwi, S. H., Pratiwi, R., Putro, S. P., and Nur, M. (2016). Corona Discharge Plasma Technology to Accelerate the Growth of Black Soybean Plants. Journal of Natural Sciences Research. ISSN 2224-3186. Vol 6. No 14.

Nugroho. U., R. A. Syaban dan N. Ernawati. (2017). Uji Efektivitas Ukuran Umbi dan Penambahan Biourine Terhadap Pertumbuhan dan Hasil Bibit Bawang Merah (Allium ascolonicum L.). Agriprima. 1 (2): 118-125. 
Nur, M. (2011). Fisika Plasma dan Aplikasinya. Semarang: Badan Penerbit Universitas Diponegoro.

Nur, M., Nasruddin, Wasiq J., dan Sumariyah. (2013). Penerapan Teknologi Plasma Untuk Mempercepat Persemaian Mangrove Sebagai Upaya Rehabilitasi Green Belt Untuk Mengatasi Abrasi. Riptek. 7 (1), 15-26.

Pramukyana. L., N. Kendarini dan Respatijarti. (2018). Respin Pemberian Konsentrasi $\mathrm{GA}_{3}$ Terhadap Pembungaan Dua Varietas Bawang Merah (Allium ascolonicum L.). Jurnal Produksi Tanaman. 6(7): 1433-1441.
Puspitasari, Indah. (2018). Respon Pertumbuhan dan Produksi Tanaman Bawan Merah (Allium cepa L.) Lokal Akibat Perbedaan Lama Radiasi Plasma. Skripsi. Depaetermen Biologi Fakultas Sains dan Matematika Universitas Diponegoro, Semarang.

Shobarudin, M dan M. Nur. (2013). Pemanfaatan Teknologi Plasma untuk Meningkatkan Kadar Nitrogen dan Protein Pellet Pakan Sapi dari Limbah Tanaman Jagung. Youngster Physics Journal 1(5): 169-176.

Tjitrosoepomo, G. (2010). Taksonomi Umum. Yogyakarta: Gajah Mada University Press. 